\title{
Studies on Optimization of Physical Growth Factors for Rapid Initiation of Anammox
}

\author{
Apurba Dey, Shubhaneel Neogi and Pradip Kumar Chaterjee
}

\begin{abstract}
Nitrogen is a major pollutant from food processing industries. Handling nitrogen pollutants is a tedious cost-effective job. The newer technologies like anaerobic ammonium oxidation (anammox) shows promising future yet lack in technical clarification of operational details and dependency at different geolocations. The start-up of the anammox process reported at a wide range of operational condition is still ambiguous. This study will attempt to ensure the investigation of uniformly operational physical parameters for the rapid start-up of anammox. This experiment was conducted in a batch culture where three $1 \mathrm{~L}$ culture bottle was inoculated with 100 $\mathrm{ml}$ sludge of $10000 \mathrm{mg} / \mathrm{L}$ VSS and $900 \mathrm{ml}$ optimized anammox media. The $\mathrm{pH}$ of the bottles was adjusted to $6.5,7.5$ and 8.5. The three sets were cultured at $25^{\circ} \mathrm{C}-55^{\circ} \mathrm{C}$ for 3 cycles and removal of ammonia and nitrite was considered as a function of optimal cellular activity of anammox bacteria. Since the growth rate of the Planctomycetes group is very slow this was omitted for the active parameter for optimization. The Box-Behnken full factorial design was considered to derive the optimal point of reaction. The result shows that the removal efficiency for both ammonia and nitrite was exponentially increased from $25-40^{\circ} \mathrm{C}$, removing $88 \%$ of ammoniacal nitrogen and complete removal of nitrite at a $\mathrm{pH}$ of 7.5. The ability to remove nitrogen drastically reduced with increasing temperature beyond $40^{\circ} \mathrm{C}$ and $\mathrm{pH}$ 7.8. The optimization of parameters suggests optimal operation at $39.7^{\circ} \mathrm{C}$ at a $\mathrm{pH}$ of 7.2 for $61.83 \mathrm{~h}$. This result will help in successful startup and operation of anammox reactor.
\end{abstract}

Keywords - Anammox; Starch Industry; Wastewater Treatment; Nitrogen Removal; Planctomycetes.

\section{INTRODUCTION}

The twenty-first century registers highest technological advancement and ease of life in history and rapid growth of technology in every sector. But with increasing population and to meet the demand the amount of industrialization required, caused havoc in terms of a massive reduction in green cover and huge industrial waste production, which intoxicated land, air and water terribly [1]. The water is the basic fundamental element of life forms and its importance is well scripted in even the oldest scripture known to humanity, the Rig-Veda [2]. Water is the most important resource for most of the human activities, for either livelihood or industrial utilization. But

Prof. (Dr.) Apurba Dey ${ }^{1 *}$ Department of Biotechnology, National Institute of Technology, Durgapur 713209, India.

Shubhaneel Neogi ${ }^{1}$ Department of Biotechnology, National Institute of Technology, Durgapur 713209, India

Dr. Pradip Kumar Chaterjee ${ }^{2}$ CSIR-Central Mechanical Engineering Research Institute, Durgapur 713209, India irresponsible utilization and lack of sense of accountability with the post-industrial revolution mindset, where it is no more considered sacred, for that a massive scarcity of potable water appeared globally. Today, nearly 1 billion people suffer in the developing world due to a lack of access to clean water [3].

Recent surveys predict that around $74 \%$ of water is used for agriculture and irrigation, $8 \%$ in domestic purpose and $18 \%$ for industrial utilization. Without a clean source of water crop production will definitely reduce in future and preserving it will be more difficult [4]. The impact of urban groundwater utilization and pollution discharge to river streams affects around $84 \%$ rural population badly, who do not have access to clean water. But the problem is more because of a lack of management and can be termed as economic scarcity instead considering it physical [5]. The global demand for water has been predicted to increase from $4600 \mathrm{~km}^{3}$ per year to 5500 $6000 \mathrm{~km}^{3}$ per year with a rate of $20-30 \%$ by 2050 from now [6]. The manufacturing sector will see a $400 \%$ increase in water demand from the year 2000-2050 according to OECD (2012) [7].

The industrial effluents contribute a larger part of aquatic pollution especially globally [8]. Corn starch industry is a major industry among food processing industries and accounts for $12 \%$ production for total starch. The wet milling of corn starch generates a huge amount of acidic wastewater with high COD and BOD load. An average range of starch industry effluent is presented in Table 1 .

TABLE I: STARCH INDUSTRY WASTEWATER CONTENTS

\begin{tabular}{ll}
\hline \multicolumn{1}{c}{ Pollutants } & \multicolumn{1}{c}{$\begin{array}{c}\text { Concentration } \\
(\mathbf{m g} / \mathbf{L})\end{array}$} \\
\hline $\mathrm{pH}$ & $3.0-4.6$ \\
$\mathrm{BOD}$ & $4560-6280$ \\
COD & $10200-20360$ \\
Total solid & $5640-7210$ \\
Dissolved solids & $4210-5980$ \\
Suspended solid & $1132-1260$ \\
KJN & $380-470$ \\
Toal & $125-272$ \\
phosphorous & \\
\hline
\end{tabular}

The carbon and nitrogen pollutants play a pivotal role in aquatic ecosystem degradation and genesis of pathogens and toxicity. The reduction of carbon pollutants receives great interest amongst industries due to the opportunity to recover resources, easily and efficiently. However, the reduction of the nitrogenous pollutants remains a tedious and costly process, and recovery is not industrially beneficial. Thus the lacuna to 
treat nitrogen before discharge contributes greatly to the eutrophication of downstream aquatic systems.

The conventional system for treatment of nitrogenous waste depends upon nitrification-denitrification (N-DN), where bacterial community degrades ammoniacal nitrogen aerobically to produce nitrate via nitrite. Then other groups of bacteria uptake the produced nitrite to reduce it to nitrogen gas anoxically. The overall process is time consuming thus increases the cost of operation and overall hydraulic retention time in the industrial treatment system.

There is a recent development in nitrogenous cycle, which suggests, anaerobic ammonium oxidation(Anammox) pathway also exists, which is a syntrophic metabolic process carried out by chemolithoautotrophic bacteria that forms monophyletic cluster under phylum Planctomycetes, where oxidation of ammonia occurs in anamoxosome in presence of nitrite as an electron acceptor to produce dinitrogen gas [9]. The suggested pathway was hypothesized to use ammonia as an electron donor and nitrite as an electron acceptor to produce nitrogen gas in the anaerobic environment within the anammoxosome of anammox bacteria [10]. The proposed reaction is as follows-

$$
\begin{gathered}
\mathrm{NH}_{4}{ }^{+}+1.32 \mathrm{NO}_{2}^{-}+0.066 \mathrm{HCO}_{3}^{-}+0.13 \mathrm{H}^{+} \rightarrow 1.02 \mathrm{~N}_{2}+ \\
0.26 \mathrm{NO}_{3}{ }^{-}+0.066 \mathrm{CH}_{2} \mathrm{O}_{0.5} \mathrm{~N}_{0.15}+2.03 \mathrm{H}_{2} \mathrm{O}
\end{gathered}
$$

The temperature and $\mathrm{pH}$ have a great impact on the growth and activity of any biological system. A number of research work was carried out earlier to understand the growth condition of anammox bacteria, which suggests mostly the load tolerance for ammoniacal nitrogen and nitrite ranging from 60-1200 mg/L [11][12]. Even after two decades of research, the ambiguity still remains about anammox because a very few research elaborates physical growth condition. The temperature tolerance was reported from $12^{\circ} \mathrm{C}$ [13][14] to $45^{\circ} \mathrm{C}$ [15]. The $\mathrm{pH}$ is discussed having a great impact on anammox bacteria [16]. In most cases, the suggested $\mathrm{pH}$ is above 7.8 [17][18]. However, higher $\mathrm{pH}$ in the starch industry promotes the formation of struvite, a salt of ammoniummagnesium phosphate, causing blockage of the treatment system. As reported in the literature, the effect of temperature and $\mathrm{pH}$ in most cases was studied in a continuous reactor with a sludge developed from the same source of inoculum from Delft university reactor [19][20]. The degree of variability within a continuous reactor treating effluent is so high that it is nearly impossible to suggest the role of a particular physicochemical factor on specific species from a syntrophic community of bacteria.

This research was conducted to evaluate the role of temperature and $\mathrm{pH}$ on indigenously developed anammox bacteria developed from aerobic sludge from a starch industry reactor. The role of community and their alteration was monitored during each change through $16 \mathrm{~S}$ metagenomic analysis. The individual effect of temperature and $\mathrm{pH}$ was studied in batch culture using synthetic anammox media specifically developed for rapid enrichment from a previous study [21] and finally, optimization was carried out using statistical modeling software Design-Expert V.08.

\section{MATERIAL AND METHODS:}

\section{A. Inoculum enrichment and analysis:}

Inoculum sludge was developed in a sequencing batch reactor (SBR) of $10 \mathrm{~L}$ volume over 780 days starting from aeration tank sludge, collected from Sukhjit Starch Industries, Narayanpur, Malda (25.409052 N, 87.8635586 E) India. The healthy colonies then collected by settling and were analyzed through $16 \mathrm{~S}$ rRNA metagenomic using Illumina platform to confirm the presence of planctomycetes group. Thereafter, 100 $\mathrm{ml}$ sludge containing approx. $10000 \mathrm{mg} / \mathrm{L} \mathrm{VSS}$ as the dry weight was transferred to three sets of $1 \mathrm{~L}$ culture bottle to use as inoculum for further test.

\section{B. Design of experiment:}

Three sets of inoculated culture bottle were added with 900 $\mathrm{ml}$ optimized synthetic wastewater containing $600 \mathrm{mg} / \mathrm{L}$ ammoniacal nitrogen, $675 \mathrm{mg} / \mathrm{L}$ nitrite, and $2000 \mathrm{mg} / \mathrm{l}$ bicarbonate source. The $\mathrm{pH}$ of the three sets was adjusted to $6.5,7.5$ and 8.5 initially. To study the effect of temperature all three sets were incubated at a very vast range of temperature i.e. $25^{\circ} \mathrm{C}$ to $55^{\circ} \mathrm{C}$ for consecutive three cycles. The removal of ammoniacal nitrogen and nitrite was measured against time as a function of optimal cellular activity of anammox bacteria. The growth rate of Planctomycetes group is very slow. Thus it was omitted as an active parameter for optimization. The actual composition of the media is given in Table 2 .

TABLE II:

\begin{tabular}{|c|c|}
\hline Component & $\begin{array}{c}\text { Quantity }(g / L / g \\
\text { VSS })\end{array}$ \\
\hline $\mathrm{KHCO}_{3}$ & 2.0 \\
\hline$(\mathrm{NH} 4)_{2} \mathrm{SO}_{4}$ & 0.60 \\
\hline $\mathrm{NaNO}_{2}$ & 0.675 \\
\hline $\mathrm{KH}_{2} \mathrm{PO}_{4}$ & 0.140 \\
\hline $\mathrm{CaCl}_{2}$ & 0.050 \\
\hline $\mathrm{MgCl}_{2}$ & 0.050 \\
\hline$*$ Trace element sol ${ }^{1}$ & $1 \mathrm{ml}$ \\
\hline$* *$ Trace element sol ${ }^{2}$ & $1 \mathrm{ml}$ \\
\hline
\end{tabular}

COMPOSITION OF SYNTHETIC ANAMMOX MEDIA [21].

\section{Chemical assessment:}

Ammoniacal nitrogen was measured by Nessler's method (D1462-92) in Hannah multi-parameter photometer (Hi-83099 2008 series) [22]. $1 \mathrm{ml}$ sample was diluted to make a final volume of $10 \mathrm{ml}$ and was added with four drops $(150 \mu \mathrm{L})$ of Nessler's reagent of one and two subsequently and mixed well and left for 3 minutes. Then the absorbance was estimated at $420 \mathrm{~nm}$ using Ammonia MR Method against $1 \mathrm{mg} / \mathrm{mL}$ ammonium chloride standard solution.

Nitrite was assessed with ferrous sulfate method, $10 \mathrm{ml}$ filtered sample was added with 10 drops of ferrous sulfate-acid solution and left for 10 minutes to react then measured at 575 $\mathrm{nm}$ against $10 \mathrm{mg} / \mathrm{mL}$ standard in multiphotometer.

The $\mathrm{pH}$ of all sample was periodically measured with Hannah digital $\mathrm{pH}$ meter calibrated with 2 point calibration by 
the standard buffer of $\mathrm{pH} 4.0$ and $\mathrm{pH} 7.0$ [23].

\section{D.Biological assessment:}

High throughput metagenomics sequencing (16S rRNA) was carried out to investigate the whole community of bacteria and from available resources to understand their role in the anammox process. The amplicon library was prepared using the Nextera XT index kit (Illumina). Primers for the amplification of the V3 forward (CCTACGGGNBGCASCAG) and V4 reverse (GATCACNVGGGTATCTAATCC) hypervariable region of $16 \mathrm{~S}$ rDNA gene of bacteria and archaea were designed in house. These primers were synthesized in Xcelris PrimeX facility. The Miseq paired-end sequence stitching was carried out using FLASH (Fast length adjustment of short reads) software to merge paired reads from a next-generation sequencing experiment. The operational taxonomic unit was chosen based on 97\% similarity and implemented through UCLUST algorithm. In the next step representative set of OTU's were prepared excluding singleton OTU's for downstream analysis. Then the assignment of taxonomic names to the sequences was carried out based on $90 \%$ sequence similarity using UCLUST algorithm, where the query was our representative sequences and subject are the curated sequences at the green-genes database. Relative abundance was determined by using OTU's. The comparative analysis was performed using the MetaCoMET web platform, to find the relative abundance between each group.

\section{E. Optimization process:}

The several physicochemical co-factors in any biological system usually influence the reaction independently. So, to comprise it into technology, mathematical modeling techniques is usually very helpful. In this experiment, to evaluate the combined effect of $\mathrm{pH}$ and temperature the response surface methodology was used in Design-Expert V.08 software, to determine maximal anammox activity in terms of ammoniacal nitrogen and nitrite removal. The results from triplicate experiments were analyzed through full factorial Box-Behnken model, considering the $\mathrm{pH}$, temperature and treatment time as input variable while maintaining initial biomass and total nitrogen load. The response between experimental and independent factors was calculated by a second order polynomial equation and represented below as equation 1.

$$
Y=\beta_{0}+\sum_{i=1}^{k} \beta_{i} X_{i}+\sum_{i}^{k} \beta_{i i} X_{i} X_{i}+\sum_{i=1}^{k-1} \sum_{j=i+1}^{k} \beta_{i j} X_{i} X_{j}
$$

Where, $\mathrm{Y}=$ predicted response, $\beta 0=$ constant, $\beta \mathrm{i}=$ linear coefficient, $\beta \mathrm{ii}=$ coefficient of the squared term, $\beta \mathrm{ij}=$ coefficient of the cross term product, and $\mathrm{k}=$ number of the independent factors.

\section{RESULTS AND DISCUSSIONS:}

\section{A. Analysis of the biological community of anammox cluster:}

The enriched cluster i.e. the inoculum for this test was first evaluated to understand community structure. The $16 \mathrm{~S}$ rRNA metagenomic study reveals the presence of a wide range of microorganism in the obtained anammox culture from the SBR of which the phylum Proteobacteria, Bacteroidetes, Firmicutes, Chlorobi, Planctomycetes, and Chloroflexi constitute more than $89 \%$ of the population. At the phylum level, the abundance of Proteobacteria was dominating sharing 35.5\% and Planctomycetes was present around $8.4 \%$ which are actually involved in anaerobic ammonium oxidation. At genus level probing it was found that Candidatus Brocadia sinica $J P N 1$ was sharing $7.3 \%$ gene pool along with $0.10 \% C$. Jettennia asiatica (SRA:SRS4263659). The detailed community structure is represented in Fig 1 .

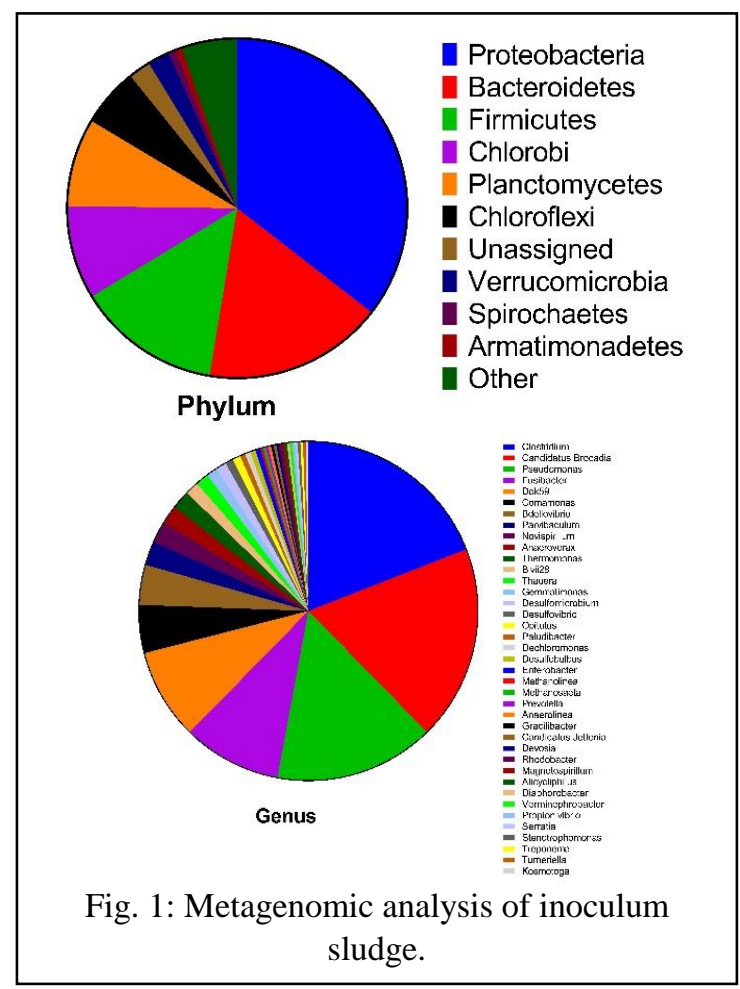

\section{B. Effect of $p H$ and temperature on the removal of ammonia:}

In anaerobic ammonium, oxidation $\mathrm{pH}$ plays a great role by altering the oxidation-reduction potential of the reactants. In this test at acidic condition i.e. at $\mathrm{pH} 6.5$ the rate of removal of ammoniacal compounds was a very slow and reduced maximum of $64.7 \%$ at $40^{\circ} \mathrm{C}$ while lowering the temperature reduces activity to $54.3 \%$ at $25^{\circ} \mathrm{C}$. At acidic $\mathrm{pH}$ zone, the specific ammonia activity (SAA) was lowest with increasing temperature beyond $400 \mathrm{C}$ and was able to remove maximum $42.3 \%$ ammonia. The most favorable condition was found near $\mathrm{pH} 7.5$ and $40^{\circ} \mathrm{C}$ reducing $88.6 \%$ ammonia from $600 \mathrm{mg} / \mathrm{L}$. 
The $\mathrm{pH}$ in the basic zone though drastically reduced ammonia removal for the given community and was able to reduce only $60 \%$ ammoniacal content irrespective of alteration of temperature. The effect of $\mathrm{pH}$ and temperature in the removal of ammonia by the developed anammox community is represented in Fig. 2.

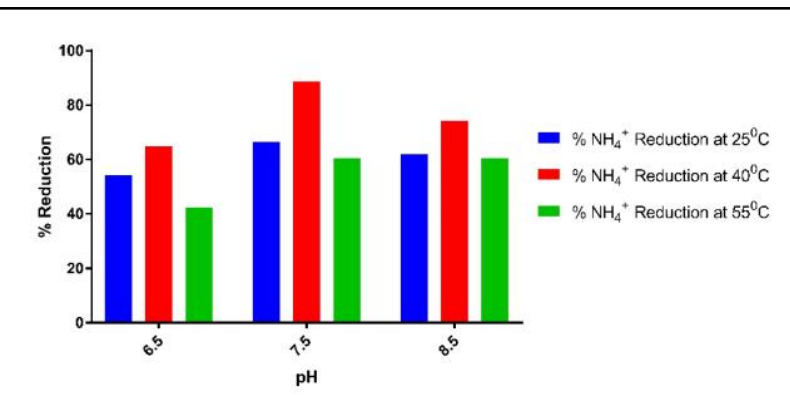

Fig. 2: Effect of $\mathrm{pH}$ and temperature in ammonia removal.

\section{Effect of $p H$ and temperature on the rmoval of nitrite:}

Nitrite acts as an electron acceptor and its uptake into anammoxosome depends upon the environmental $\mathrm{pH}$. In this investigation, the removal of nitrite was found very low and in a similar ratio for lower $\mathrm{pH}$ range where the maximum removal was observed $64 \%$ at $\mathrm{pH} 6.5$. However, at the neutral range and in the mesophilic reaction zone, almost $88.6 \%$ nitrite disappeared within $36 \mathrm{~h}$. But with increasing $\mathrm{pH}$, the removal of nitrite was found to be inhibited and reduced to $60 \%$ by $72 \mathrm{~h}$ at a very slow pace. The removal efficiency at various $\mathrm{pH}$ and temperature is represented in Fig. 3.

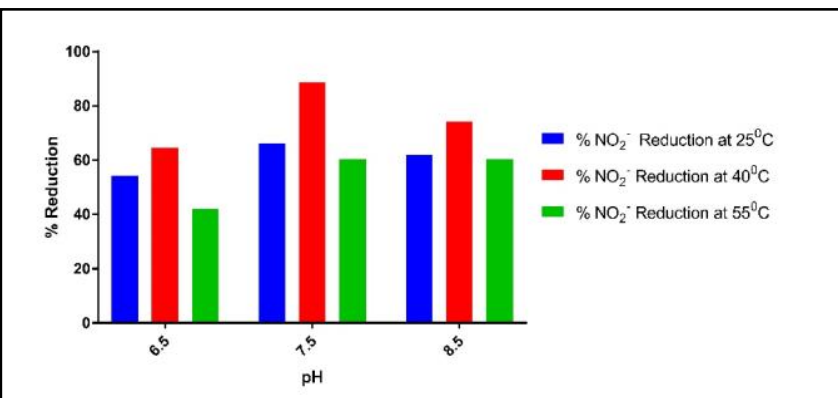

Fig. 3: Effect of $\mathrm{pH}$ and temperature in nitrite removal.

\section{D.Optimum point analysis for of ammonia removal:}

The Box-Behnken full factorial design [10] represents the interaction of major influential factors for any given experiment. F-test ANOVA was performed to evaluate the significance of the model, where Prob.>F is less than 0.05 , indicates the model terms are significant. The independent parameters i.e. $\mathrm{pH}$ and temperature were found significantly influential in ammoniacal nitrogen removal and shown in equation 2.

Ammoniacal nitrogen $=5907.38194-1244.1667 * p H-$ $32.192222 *$ Temperature $-10.641667 *$ Treatment time $0.5333333 * p H *$ Temperature $-0.4166667 * p H *$ Treatment time $-0.02666667 *$ Temperature $*$ Treatment time $-84.25 *$ pH2 -0.44777778*Temperature ${ }^{2}-0.08472222 *$ Treatment time ${ }^{2}$ (Eq. 2)

The regression value i.e. $\mathrm{R}^{2}$ of 0.9596 is in agreement with a predicted $R^{2}$ value of 0.8908 and adjusted $R^{2}$ of 0.9077 . The precision and reliability of the test were analyzed using the residual variation, using a coefficient of variance relative to the size of the mean. The low coefficient of variation $(\mathrm{CV})$ value of $13.96 \%$, implies sufficient precision and reliability of the experimental results. The standard deviation and mean value for ammonia removal were 45.08 and 322.94 respectively. The influence of the treatment parameters on COD removal from starch industry wastewater was studied using 3-D (three dimensional) plots, as shown in Fig 4.

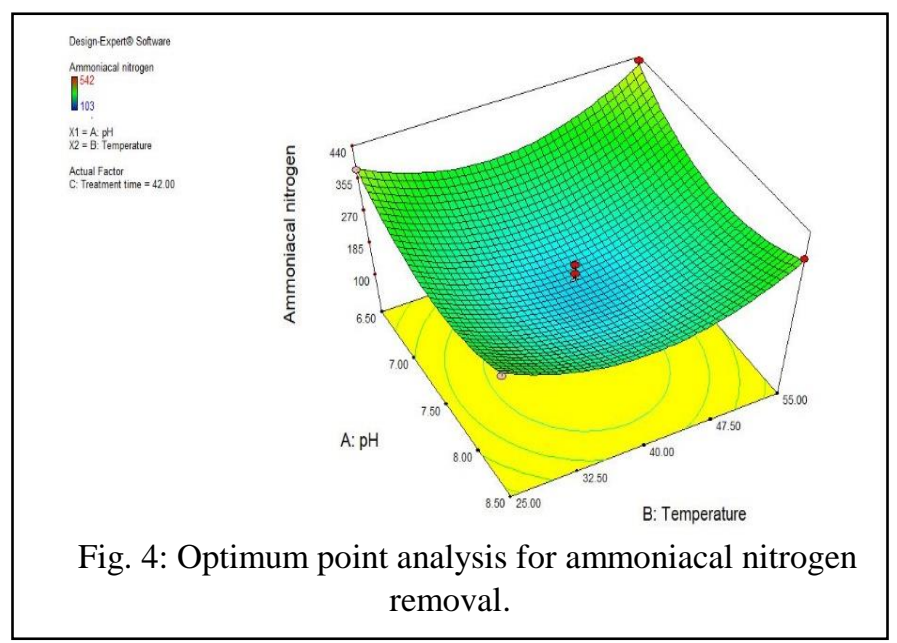

\section{E. Optimum point analysis for of nitrite removal:}

The model predicts the F-value of 11.31 and $\mathrm{P}<0.05$ confirming the model accuracy. The predicted $\mathrm{R}^{2}$ of 0.7763 was in agreement with actual $R^{2} 0.9356$ and adjusted $R^{2}$ 0.8529 . The coefficient of variance was also significantly low, 17.89 against the standard deviation of 63.76 and mean value was 356.23. The influence of parameters on nitrite removal is represented in equation 3 .

Nitrite $=7506.833278-1671.091667 * \mathrm{pH}-33.07722222 *$ Temperature $-9.409388889 *$ Treatment time $-0.533333333 *$ $\mathrm{pH} *$ Temperature $-0.475 * \mathrm{pH} *$ Treatment time -

$0.016111111 *$ Temperature $*$ Treatment time $-112.8 * \mathrm{pH}^{2}-$ $0.492444444 *$ Temperature $^{2}-0.091166667 *$ Treatment time $^{2} \quad$.........Eq. 3 .

The model relies on a 45-degree angle from the predicted value. The responses of the different variable are represented in Fig. 5.

\section{F. Optimization of the process:}

The optimization of the process always includes multiple goals; in this case, feasible removal of ammoniacal nitrogen and nitrite by anammox bacteria within shortest possible time was the main objective. The Box-Behnken model in Design- 
Expert V.08 software predicted a minimum of $61.8 \mathrm{~h}$ treatment at $\mathrm{pH} 7.2$ and $39^{\circ} \mathrm{C}$ will be required for optimum anammox activity. The predictive values are represented in Table 2 .

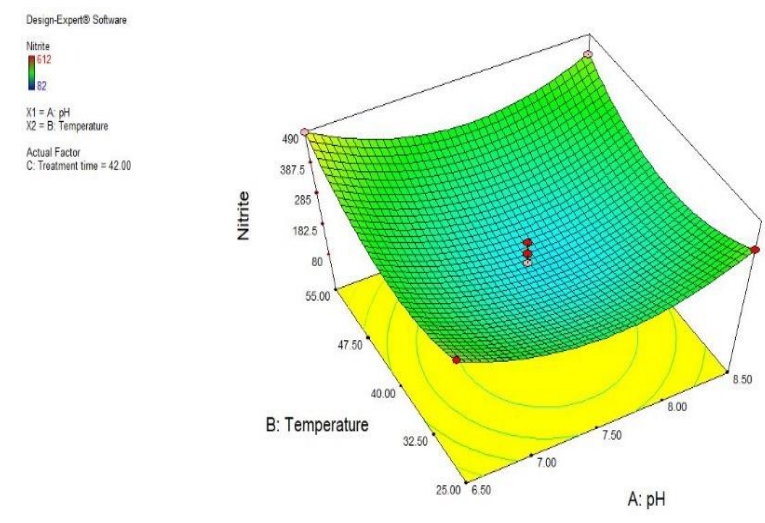

Fig. 5: Optimum point analysis for nitrite removal.

TABLE III:

\begin{tabular}{|c|c|c|c|c|}
\hline \multicolumn{5}{|c|}{ OPTIMUM POINT PREDICTION. } \\
\hline Factor & Name & Level & Low Level & High Level \\
\hline A & $\mathrm{pH}$ & 7.263 & 6.5 & 8.5 \\
\hline B & Temperature & 38.94 & 25 & 55 \\
\hline $\mathrm{C}$ & $\begin{array}{l}\text { Treatment } \\
\text { time }\end{array}$ & 61.83 & 12 & 72 \\
\hline Response & Prediction & $\begin{array}{c}S E \\
\text { Mean }\end{array}$ & $\begin{array}{c}95 \% \text { CI } \\
\text { low }\end{array}$ & 95\% CI high \\
\hline $\begin{array}{l}\text { Ammoniaca } \\
1 \text { nitrogen }\end{array}$ & 327.1536 & 20.21 & 279.34 & 374.96 \\
\hline Nitrite & 347.7719 & 28.59 & 280.16 & 415.38 \\
\hline
\end{tabular}

\section{CONCLUSION}

The ambiguity about culture condition, especially the role of temperature and $\mathrm{pH}$ in anammox bacteria is not adequately studied. The basic objective of the study was to evaluate the growth condition of anammox bacteria in batch culture. In this experiment the anammox bacteria were identified, belonging to planctomycetes family, namely Candidatus Brocadia sinica JPN1 and C. Jettennia asiatica was very active in mesophilic temperature zone and shown a good removal in mildly basic wastewater. The optimization for ammoniacal compounds with respect to nitrite predicts that at $\mathrm{pH} 7.2$ and $39^{\circ} \mathrm{C}$ minimum $61.83 \mathrm{~h}$ treatment will be required to achieve the significant removal by anammox bacteria.

The work leaves the further scope to evaluate optimum condition for anammox bacteria isolated from different climate conditions. This also promotes further interest of application in real time reactor for rapid initiation and enrichment of anammox starting from natural sources.

\section{ACKNOWLEDGEMENT}

The authors are grateful to Director, National Institute of Technology, Durgapur, India, Director, CSIR-Central Mechanical Engineering Research Institute, Durgapur, India and Sukhjit Starch Industries, Malda, India for constant support, encouragement and permission to publish this paper.

\section{CONFLICT OF INTEREST}

The authors have declared no conflicts of interest.

\section{REFERENCES}

[1] M.Z.Jacobson, Review of solutions to global warming, air pollution, and energy security. Energy Environ. Sci. 2009, 2, 148-173. https://doi.org/10.1039/B809990C

[2] S., Radhakrishnan, Indian Philosophy. Mind 1928, xxxvii, 130-131. https://doi.org/10.1093/mind/XXXVII.145.130

[3] World Health Organization, Connecting Global Priorities: Biodiversity and Human Health. WHO Press 2015.

[4] WWAP (United Nations World Water Assessment Programme), The United Nations World Water Development Report 2015: Water for a Sustainable World; facts and figures. 2015.

[5] H., Fyles, Madramootoo, C., Water Management, in: Emerging Technologies for Promoting Food Security, Elsevier, 2016, pp. 117134.

https://doi.org/10.1016/B978-1-78242-335-5.00006-8

[6] A. Udias, A. Gentile, P. Burek, A. de Roo, et al., Multi-Criteria Framework to Assess Large Scale Water Resources Policy Measures. Water 2016, 8, 370 . https://doi.org/10.3390/w8090370

[7] A.M. Bassi, Z. Tan, A. Mbi, Estimating the impact of investing in a resource efficient, resilient global energy-intensive manufacturing industry. Technol. Forecast. Soc. Change 2012, 79, 69-84. https://doi.org/10.1016/j.techfore.2011.05.011

[8] Y. Hu, H. Cheng, Water pollution during China's industrial transition. Environ. Dev. 2013, 8, 57-73. https://doi.org/10.1016/j.envdev.2013.06.001

[9] M. Kumar, A. Daverey, J.-D. Gu, J.-G. Lin, Anammox Processes, in: Current Developments in Biotechnology and Bioengineering, Elsevier, 2017, pp. 381-407. https://doi.org/10.1016/B978-0-444-63665-2.00015-1

[10] M.S.M. Jetten, O. Slickers, M. Kuypers, T. Dalsgaard, et al., Anaerobic ammonium oxidation by marine and freshwater planctomycete-like bacteria. Appl. Microbiol. Biotechnol. 2003, 63, 107-114. https://doi.org/10.1007/s00253-003-1422-4

[11] M. Ali, L.-Y. Chai, C.-J. Tang, P. Zheng, et al., The Increasing Interest of ANAMMOX Research in China: Bacteria, Process Development, and Application. Biomed Res. Int. 2013, 2013, 1-21. https://doi.org/10.1155/2013/134914

[12] B. Hu, L. Shen, X. Xu, P. Zheng, Anaerobic ammonium oxidation (anammox) in different natural ecosystems: Table 1. Biochem. Soc. Trans. 2011, 39, 1811-1816. https://doi.org/10.1042/BST20110711

[13] T.L.G. Hendrickx, Y. Wang, C. Kampman, G. Zeeman, et al., Autotrophic nitrogen removal from low strength waste water at low temperature. Water Res. 2012, 46, 2187-2193. https://doi.org/10.1016/j.watres.2012.01.037

[14] J. Dosta, I. Fernández, J.R. Vázquez-Padín, A. Mosquera-Corral, et al., Short- and long-term effects of temperature on the Anammox process. J. Hazard. Mater. 2008, 154, 688-693. https://doi.org/10.1016/j.jhazmat.2007.10.082

[15] M. Tomaszewski, G. Cema, A. Ziembińska-Buczyńska, Influence of temperature and $\mathrm{pH}$ on the anammox process: A review and metaanalysis. Chemosphere 2017, 182, 203-214. https://doi.org/10.1016/j.chemosphere.2017.05.003

[16] J.M. Carvajal-Arroyo, D. Puyol, Li, G., R. Sierra-Álvarez, et al., The role of $\mathrm{pH}$ on the resistance of resting- and active anammox bacteria to $\mathrm{NO}_{2}{ }^{-}$inhibition. Biotechnol. Bioeng. 2014, 111, 1949-1956. https://doi.org/10.1002/bit.25269

[17] L.W. Jaroszynski, N. Cicek, R. Sparling, J.A. Oleszkiewicz, Importance of the operating $\mathrm{pH}$ in maintaining the stability of anoxic ammonium oxidation (anammox) activity in moving bed biofilm reactors. Bioresour. Technol. 2011, 102, 7051-7056. https://doi.org/10.1016/j.biortech.2011.04.069

[18] C.J. Tang, P. Zheng, Q. Mahmood, J.W. Chen, Start-up and inhibition analysis of the Anammox process seeded with anaerobic granular sludge. J. Ind. Microbiol. Biotechnol. 2009. https://doi.org/10.1007/s10295-009-0593-0 
[19] M. Oshiki, M. Shimokawa, N. Fujii, H. Satoh, et al., Physiological characteristics of the anaerobic ammonium-oxidizing bacterium "Candidatus Brocadia sinica." Microbiology 2011. https://doi.org/10.1099/mic.0.048595-0

[20] S.-Q. Ni, J. Zhang, Anaerobic Ammonium Oxidation: From Laboratory to Full-Scale Application. Biomed Res. Int. 2013, 2013, 1-10. https://doi.org/10.1155/2013/469360

[21] S. Neogi, A. Dey, P.K. Chaterjee, Studies on Rapid Initiation of Anammox Process for Starch Industry Effluent Treatment, in: Jana, S., Jana, S. (Eds.), Waste Water Recycling and Management, Springer Singapore, Singapore 2019, pp. 97-110. https://doi.org/10.1007/978-981-13-2619-6_9

[22] ASTM Standard D1426, Standard Test Methods for Ammonia Nitrogen In Water. ASTM Int. 2008, 1-7.

[23] ASTM, ASTM D698: Standard Test Methods for Laboratory Compaction Characteristics of Soil Using Standard Effort (12 $400 \mathrm{ft}-$ lbf/ft3 (600 kN-m/m3)). ASTM Int. 2012, 3, 1-13. 